Volume 1 Nomor 2, September 2020, 39-46

Journal Homepage: http://ejurnal.ung.ac.id/index.php/jgej

\title{
DAYA TAMPUNG TAMAN MACAN SEBAGAI TAMAN KOTA DALAM PEMANFAATAN FUNGSI WISATA DI KOTA MAKASSAR
}

\author{
Muhammad Musawantoro ${ }^{\mathrm{a}}$, Masri Ridwan ${ }^{\mathrm{b}}$ \\ ${ }^{a}$ Politeknik Pariwisata Makassar,Jl.Gunung Rinjani Kota Mandiri Tanjung Bungan,Makassar, 90244, Indonesia \\ ${ }^{b}$ Politeknik Pariwisata Makassar,Jl.Gunung Rinjani Kota Mandiri Tanjung Bungan,Makassar, 90244, Indonesia
}

\begin{tabular}{ll}
\hline INFO ARTIKEL & ABSTRACT \\
\hline Status artikel: & $\begin{array}{l}\text { The importance of this research is a description of the maximum capacity of a tourist } \\
\text { area, to sustain the urban forest which has many functions for urban communities, seeing } \\
\text { Diterima: } 12-03-2020\end{array}$ \\
$\begin{array}{l}\text { an increase in the population of } 3.7 \% \text { and activities around the urban forest area in } \\
\text { Makassar, it is necessary to study the maximum capacity, the study was conducted with a } \\
\text { Tersedia online: } 04-09-2020 \\
\text { qualitative method with a survey approach, the results of the study explained that the }\end{array}$ \\
$\begin{array}{l}\text { urban forest was known as the Macan Park assuming operating hours for } 8 \text { hours, then } \\
\text { for urban forest or tiger park, Makassar City is PCC }=4,900 \mathrm{~m} 2 / 65 \mathrm{~m} 2 \mathrm{x} 4 . \text { Then the } \\
\text { Urban Forest, Capacity, Taman Macan, } \\
\text { maximum number of visitors can be obtained per day is } \pm 302 \text { people with the number of } \\
\text { needs per person long enjoying a 2-hour visit. The conclusion of the importance of the } \\
\text { application of a maximum capacitance in an area is to support the sustainability of the }\end{array}$ \\
area with a conservation approach
\end{tabular}

Muhammad Musawantoro

Politeknik Pariwisata

Makassar,Jl.Gunung Rinjani Kota

Mandiri Tanjung Bunga,Makassar,

90244, Indonesia

Email:

musawantoro@poltekparmakassar.ac.id

DOI: 10.34312/jgej.v1i2.5232

Copyright (C) 2020 JGEJ-UNG

All Rights Reserved.

\begin{abstract}
ABSTRAK
Pentingnya penelitian ini adalah gambaran terhadap daya tampung maksimal sebuah kawasan hutan di perkotaan, sebagai upaya pelestarian dari hutan kota yang memiliki banyak fungsi untuk masyarakat urban, melihat peningkatan jumlah penduduk 3,7\% dan aktifitas sekitar kawasan hutan kota di Makassar, perlu dilakukan pengkajian maximal capasity, penelitian dilakukan dengan metode kualitatif dengan pendekatan survey, hasil penelitian menjelaskan kalau hutan kota yang di kenal dengan Taman macan dengan asumsi jam operasional selama 8 jam, maka untuk Hutan kota atau taman macan, Kota Makassar adalah $\mathrm{PCC}=4,900 \mathrm{~m}^{2} / 65^{\mathrm{m} 2} \mathrm{x} 4$. Maka dapat di peroleh jumlah pengunjung maksimal perhari itu adalah \pm 302 orang dengan jumlah kebutuhan perorang lama menikmati kunjungan 2 jam. Kesimpulan pentingnya penerapan sebuah kapasital maksimal pada sebuah kawasan adalah guna mendukung kelestarian dari kawasan tersebut dengan pendekatan konservasi.
\end{abstract}

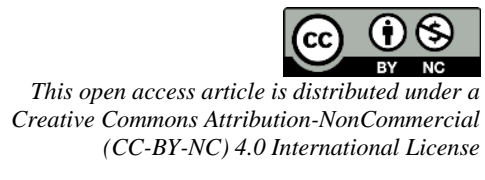

\section{Pendahuluan}

Kebutuhan akan terpenuhinya ruang terbuka hijau di berbagai negara berkembang dan maju menjadi pemikiran utama bagi masyarakat karena telah menjadi sebuah kebutuhan utamanya masyarakat di perkotaan. Salah satu pemanfaatan kawasan hutan kota melalui aktivitas berwisata. Berwisata akan memberi pengalaman baru atau kenangan yang menjadi sebuah cerita yang menarik untuk di bahas dan didiskusikan pada pergaulan sosial individu maupun kelompok. Salah satu bentuk pemanfaatan waktu luang melalui kegiatan berwisata (Sujali dalam Musawantoro dan Ridwan, 2019). Akan tetapi, kelestarian hutan kota patut menjadi perhatian utamanya semua pihak, sehingga dapat berfungsi sebagai kawasan wisata juga sebagai ruang hijau, yang dapat difungsikan sebagai area rekreasi.

Kampanye melestarikan kawasan hutan kota telah dilakukan oleh sejumlah negara. Studi kasus pada negara Kamerun memotivasi masyarakatnya untuk mematuhi perjanjian hutan internasional. Tidak ada perhatian yang sama-sama diberikan pada evaluasi mekanisme kontrol teknis yang ada untuk kegiatan penebangan di negara-negara target, yang sampai batas tertentu dapat memberikan dasar konsensus untuk pembentukan sistem pelacakan kayu dan jaminan legalitas yang lebih tepat (Andong \& Ongolo, 2020). Sementara itu sebagai upaya dalam pelestarian hutan Belgrad di istambul dilakukan dengan perencanaan 
dengan pendekatan pada pemetaan kesuaian tempat rekreasi (Recreation Area) (Yes \& Cieszewski, 2020), melihat kebutuhan perencanaan tersebut di atas maka sebaiknya area rekreasi memiliki Fasilitas yang dapat di kategorikan dengan sajian atraksi, akomodasi, amenitas, aksibilitas (Musawantoro \& Ridwan, 2019)

Penataan sebuah kawasan tidak terlepas dari penataan lingkungan yang baik sebagai tindakan pada kepedulian terhadap kelangsungan atau kelestarian lingkungan utamanya dari model wisata alam seperti salah Hutan Kota. Berbagai upaya yang telah dilakukan dari berbagai negara maupun wilayah tertentu yang memiliki kekayaan alam yang masih terjaga. Seperti yang telah dilakukan oleh (Baumeister et al., 2020), sebagai kepedulian terhadap kelestarian hutan yang ber ada ki sekitar pemukiman sebagi langkah mengukur tingkatan dampak yang bisa terjadi pada hutan kota, "Rasio gender untuk sampel acak adalah 50/50. Kami mengirim selebaran untuk mengiklankan penelitian ke 9.332 rumah - berlokasi di kota-kota yang berdekatan dengan hutan penelitian (Distrik Stuttgart 3.274, distrik Karlsruhe 3.194, distrik Heidelberg 2.859)."

Adapun langkah-langkah yang di perlukan diperhatikan dan dilaksanakan oleh pengelolah seperti yang di jelaskan pada Undang-undang no. 32 tahun 2009 tentang perlindungan dan pengelolaan lingkungan hidup pasal 1 Ayat 7, berikutnya dengan konsep Green Industry memungkinkan wisatawan dalam kelompok kecil ataupun besar berupaya dalam mempertahankan kualitas obyek dan dayatarik alam secara berkala dan berkelanjutan, Peningkatan populasi akan berdampak terhadap tehnologi untuk memenuhi kebutuhan yang dapat berdampak pada kualitas lingkungan. Pentingnya menjaga lingkungan adalah upaya demi keberlangsungan dan kelestarian lingkungan perkotaan dengan mengaitkan pengelolah dengan memperhatikan aspek pertumbuhan kota yang tidak bisa di bendung dengan berbagai dimensi kegiatannya yang begitu aktif dan juga pada sisi lain, untuk meramalkan potensi perkembangan urbanisasi (BonillaBedoya et al., 2020)

Peningkatan kunjungan wisatawan akan semakain memberikan dampak terhadap lingkungan karena semakin banyaknya tekanan fisik terhadap daya dukungnya, (Fandeli,2018,65), Selain itu dampak lingkungan dapat di sebabkan karena adanya alat transportasi, pembangunan fasilitas wisata, tekanan terhadap sumber daya alam, perusakan habitat liar serta polusi dan pencemaran limbah lainnya, dampakdampak tersebut bila di perhatikan akibat adanya aktivitas oleh pengunjung pada daya Tarik wisata. Keterlibatan dari berbagai kalangan seperti masyarakat perkotaan dan institusi juga pemerintahan yang mengatur dan memantau berbagai penggunaan hutan bersama untuk mencegah penipisan sumber daya di Abad Pertengahan. Penggantian pemerintahan masyarakat tradisional maupun masyarakat perkotaan (Guadilla-Sáez et al., 2020)

Perlunya pengkajian terhadap daya tampung kunjungan dengan menetapkan batas maksimal kunjungan dengan menggunakan rumusan daya dukung lingkungan fisik (physical carrying capacity) PCC dan daya dukung sosial serta kesan wisatawan saat berwisata, Penetapan jumlah kunjungan maksimum suatu area harus didasarkan pada kondisi fisik, biologi, dan kondisi manajemen pada area dengan pertimbangan daya dukung fisik, penerapan metode PCC ini memperhatikan beberapa elemen penting antara lain aliran wisatawan (Tourism Flows), ukuran area, jumlah maksimum ruang yang tersedia untuk masing-masing wisatawan bergerak bebas dan waktu kunjungan (Fandely, 2018:71). Oleh karena itu , penting untuk memahami apakah dan mengapa pengunjung taman saat ini merasa atau tidak diterima di area alami. Tidak semua pengguna taman kota mengakses atau mengalami area alami perkotaan dengan cara yang sama, dan asosiasi positif dan negatif yang mereka kembangkan akan memengaruhi kemampuan mereka untuk memperoleh manfaat dari ruang-ruang ini.penting bagi kita selanjutnya untuk mengetahui kemampuan daya tampung lahan (Eraku, 2018)

Menjaga kelestarian kawasan wisata Hutan Kota bukan hanya di bebankan ke pengelolah melaikn di perlukan pula partisipasi masyarakat, serta kepedulian dari berbagai aspek, dengan mengutamakan kelestarian akan memberi dampak terhadap masyarakat disekitar kota utamanya akan pemenuhan oksigen $\mathrm{H}^{2} \mathrm{O}$ yang baik serta filter untuk emilsi dari kegiatan akomodasi di kota, selain itu dapat di manfaatkan sebagai pusat pembelajaran bagi masyarakat perkotaan perihal pentingnya ruang terbuka hijau (Andong \& Ongolo, 2020). Kebanyakan masyarakat menilai bahwa menikmati alam bebas itu adalah dengan menikmati luasnya wilayah yang alami, dengan cara menikmati sajian termasuk udara segar, angin, tenang, keindahan, teduh, ruang terbuka, pemandangan air. Dengan pemanfaatan lahan yang terbatas juga akan memberikan peluang terhadap kegiatan seperti membawa anak-anak ke taman adalah penggunaan area yang paling umum (Sonti et al., 2020)

Hutan Kota merupakan kelangkaan yang di miliki Kota, disamping jenis tanaman yang ada sebagian berumur ratusan tahun sehingga sangat perlu di perhatikan dan menjadi prioritas damam kelangsungan atau 
keberlajutannya, keterlibatan elemen masyarakat dan pemerintahan merupakan hal terpenting dalam pelestarian hutan kota. (Ordóñez et al., 2020) dan (Mondal et al., 2020) Taman macam adalah salah satu pilihan tepat di jadikan obyek karena dengan melihat letak yang berada tepat di pusat kota dengan berbagai aktifitas perkotaan, selanjutnya pertumbuhan penduduk perkotaan dengan berbagai aktifitasnya akan berdampak pada aktifitas di kawasan hutan kota (Taman Macan), seperti sebagai kawasan santai, berolahraga, berdagang, bersosialisasi, arena bermain dan sebaginya akan meningkat sementara kawasan memiliki keterbatasan daya tampung, bila masalah ini di biarkan maka akan terjadi eksploitasi terhadap kawasan tanpa memikirkan kelestarian, apabilah pengunjung melebihi kapasitas daya tampung bisa berdampak seperti tingginya fandalism, kerawanan kriminalitas, pengelolaan sampah dan limbah, dan lainnya yang bisa menjadi potensi. Berikutnya penelitian ini merupakan salah satu langkah yang sederhana dalam menjaga kelestarian Hutan Kota tersebut, yaitu dengan mengidentifikasi daya tampung pengunjung atau membatasi jumlah kunjungan dengan pertimbangan kebutuhan ruang bebas bagi pengunjung di Hutan Kota, Berikut ini adalah merupakan rumusan yang dapat ditarik bahwa : (1) Bagaimana kondisi eksisting Hutan Kota (Taman Macan) di kota makassar ; (2) bagaimana daya tampung Hutan Kota (Taman Macan) di Kota Makassar.

\section{Metode}

\subsection{Metode penelitian}

Penelitian ini diawali dengan kegiatan survey pada lokasi Hutan Kota dengan Nama Taman Macan yang terletak di pusat Kota Makassar, kemudian di kaji dengan menggunakan analisa melalui pendekatan 5 komponen dayatarik wisata berupa 5A (Amenitas, Aksebilitas, Akomodasi, Atraksi, Aktivitas), merupakan acuan dalam mendeskripsikan perihal data yang di peroleh baik dari responden maupun data yang di peroleh dari pengamatan langsung, juga badan statistik Kota Makassar maupun pengelolah, salim, haidir (2019: 58) Metode penelitian pada penelitian ini adalah kualitatif menjelaskan secara singkat dan padat tentang kejadian dilapangan dengan survey (existing condition), selanjutnya aktifitas survey ini dilakukan pada hari yang berbeda yaitu di hari kerja dan di hari libur karena dari kedua waktu tersebut terdapat perbedaan jumlah pengunjung, pada hari kerja jumlah pengunjung $\pm 125-261$ orang sedangkan di hari libur dapat meningkat sekitar 40\% - 80\% karena banyaknya kegiatan yang dilakukan di Taman Macan tersebut, perihal ini menceritakan kondisi sesungguhnya pada Hutan Kota di Kota Makassar. Untuk pengambilan data di peroleh melalui data primer dan data sekunder, untuk data sekunder di lakukan wawancara dengan pengelolah dan wawancara dengan pengunjung yang dilakukan dengan tehnik eksidential yaitu mengumpulkan sebanyakbanyaknya data dari pengunjung yang berpotensi dan presentatif. Alfianika (2018: 162). Kemudian dari data yang telah di peroleh maka dilanjutkan dengan pengukuran tentang kapasitas dukungan dengan pendekatan PCC physical carrying capacity yaitu pengukuran terhadap kemampuan daya dukung kapasitas pengunjung yang relevan yang sebaiknya di terapkan pada destinasi / daya tarik wisata (fandely,2018).

\subsection{Desain penelitian}

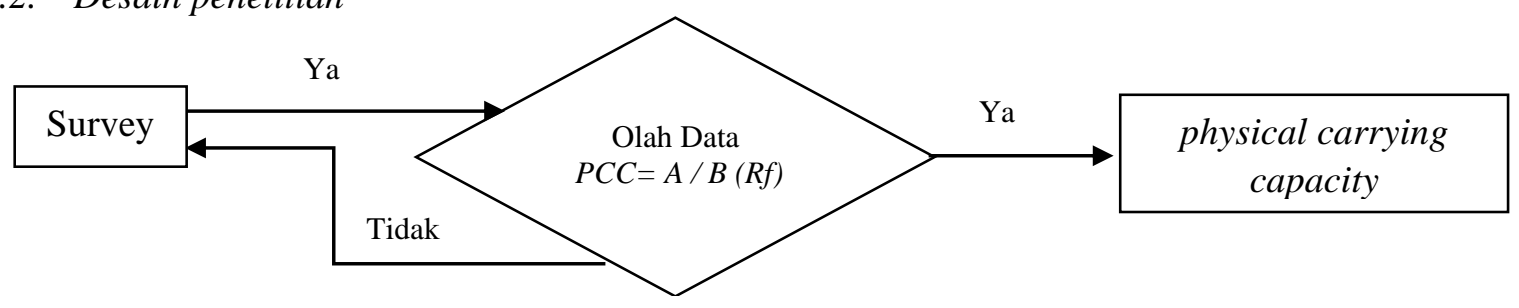

Gambar 1. Desain penelitian

\subsection{Persamaan}

Daya dukung lingkungan fisik atau physical carrying capacity (PCC) dapat dirumuskan dengan:

$P C C=A / B(R f)$

Dimana:

PCC : Jumlah maksimum Pengunjung, dan

A : Area yang tersedia untuk umum,

B : luas kebutuhan pengunjung / orang $\left(65 \mathrm{~m}^{2}\right)$, dengan kebutuhan

Rf : Faktor Rotasi (jumlah kunjungan perhari)/ lama jam buka 


\section{Hasil dan Pembahasan}

Aktifitas perkotaan tidak dapat di bendung karena kota merupakan sebuah simbol pergerakan perekonomian dari wilayah, aktifitas dan pembangunan sarana penunjang akan berdampak terhadap penyediaan lahan kosong yang dapat dijadikan ruang terbuka hijau. Aktivitas ekonomi tersebut tidak lepas dari interaksi antar individu serta kelompok (Kobi dan Hendra, 2020). Melihat peningkatan sebaran jumlah penduduk sekitar $\pm 3,7 \%$ di kota makassar dari tahun 2016-2019 bisa menjadi pemicu penggunaan lahan. dan meningkatnya aktifitas sekitar kawasan hutan kota di Makassar, dapat di lihat pada tabel 1. Pertumbuhan penduduk perkecamatan di Kota Makassar:

Tabel 1. Pertumbuhan Penduduk Perkecamatan, Kota Makassar2016-2019

\begin{tabular}{|c|c|c|}
\hline \multirow[t]{2}{*}{ Kecamatan } & \multicolumn{2}{|c|}{$\begin{array}{c}2019 \\
\text { Jumlah Penduduk (Jiwa) }\end{array}$} \\
\hline & Laki laki & \\
\hline Mariso & 30609 & 29890 \\
\hline Mamajang & 30129 & 31323 \\
\hline Tamalate & 102128 & 103413 \\
\hline Rappocini & 82162 & 87959 \\
\hline Makassar & 42553 & 42962 \\
\hline Ujung Pandang & 13716 & 15338 \\
\hline Wajo & 15470 & 15983 \\
\hline Bontoala & 27886 & 29311 \\
\hline Ujung Tanah & 18037 & 17497 \\
\hline Sangkarang & 7239 & 7292 \\
\hline Tallo & 70303 & 70027 \\
\hline Panakukkang & 73971 & 75693 \\
\hline Manggala & 75094 & 74393 \\
\hline Biringkanaya & 110138 & 110318 \\
\hline Tamalanrea & 56533 & 59310 \\
\hline Kota Makassar 2019 & 755968 & 770709 \\
\hline Kota Makassar 2016-2018 & 727314 & 742287 \\
\hline
\end{tabular}

Sumber: Data BPS Kota Makassar 2020

\subsection{Eksisting Hutan Kota (Taman Macan)}

Hasil survey dilakukan menemukan beberapa eksisting yang terjadi di taman macan tersebut yang di golongkan seperti, Amenitas, Aksibilitas, Akomodasi, Atraksi, Aktivitas, terlebih dahulu kita melihat peta lokasi taman macan dengan luas area sekitar 0.489 ha $=4899 \mathrm{~m}^{2}$ seperti pada gambar 1 . Peta lokasi Taman Macan di Kota Makassar. 


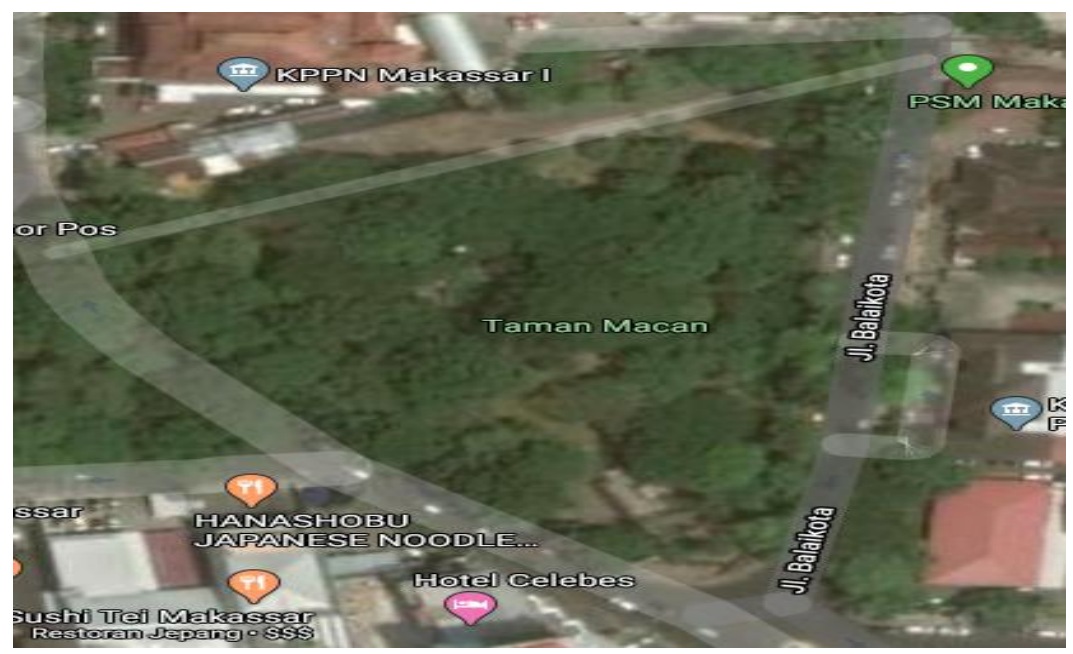

(a)

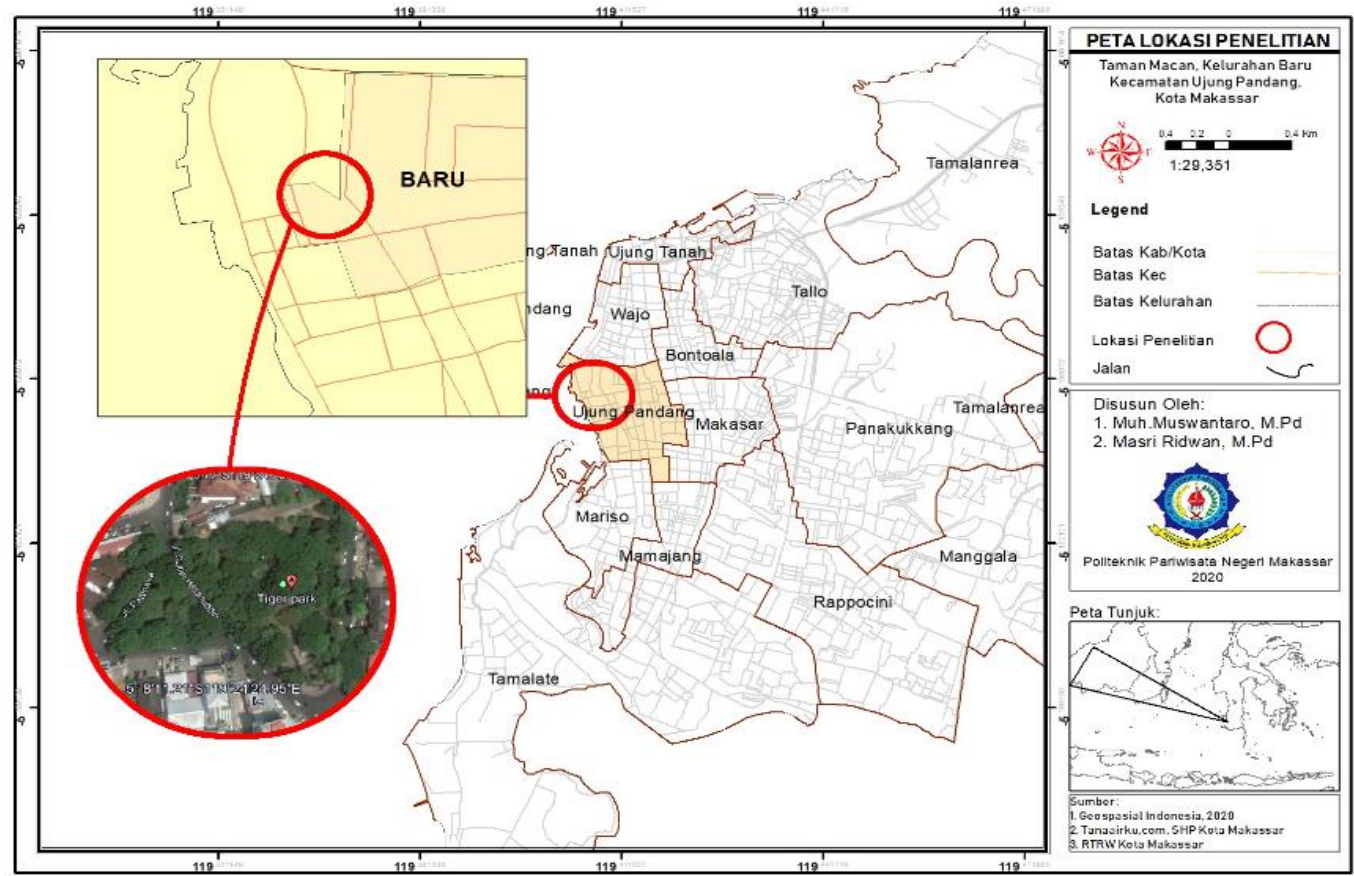

(b)

Gambar 2. Peta lokasi Taman Macan di Kota Makassar

Berikutnya merupakan gambaran kondisi eksisting taman macan yang di golongkan dengan mengunakan pendekatan 5 aspek seperti pada Tabel 1. Pertumbuhan Penduduk Perkecamatan, Kota Makassar 2016-2019; (1) Amenitas untuk kondisi eksisting amenitas ini sendiri bisa dikatakan cukup memadai dalam upaya memberikan pelayanan bagi pengunjung taman macan walaupun letak dari amanitas itu sendiri di luar dari kawasan taman macan tersedianaya kuliner tradisional di sekitar kawasan, selain itu bagi pengunjung yang memerlukan air mineral untuk minum juga tersedia fasitas tersebut di lingkungan taman macan; (2) permasalahan untuk aksebilitas menuju taman macan tidak diragukan dengan kondisi jalan yang sangat baik karena terletak di pusat Kota Makassar, tersedia pula setapak yang dapat di gunakan bagi pengunjung; (3) aktifitas yang menjadi aktifitas faporit adalah joging, senam, membaca, tersedia pula lahan kosong yang dapat di pergunakan untuk aarea berkumpul; (4) untuk atraksi yang dapat di jumpai di taman macan yang paling utama adalah rindang pohon hijau, penyediaan udara segar; (5) Akomodasi yang dapat di jumpai di sekitar taman macan adalah hotel berbintang. 
Tabel 2. Kondisi Eksisting Hutan Kota

\begin{tabular}{lccc}
\hline Fasilitas & ada & jumlah & Keterangan \\
\hline Amenitas & $\sqrt{ }$ & 5 & $\begin{array}{c}\text { Rumah makan Kuliner } \\
\text { tradisional, Kursi taman }\end{array}$ \\
\hline Akomodasi & $\sqrt{ }$ & 4 & Hotel berbintang \\
\hline Aksebilitas & $\sqrt{ }$ & $350 \mathrm{~m}$ & $\begin{array}{c}\text { Jalan beraspal, serta } \\
\text { setapak dalam kawasan }\end{array}$ \\
\hline Atraksi & $\sqrt{ }$ & Setip hari & $\begin{array}{c}\text { Taman Hijau } \\
\text { Aktifitas }\end{array}$ \\
\hline
\end{tabular}

\subsection{Daya Tampung pengunjung}

Upaya pelestarian hutan kota adalah langka yang bijak demi kelestarian lingkungan di perkotaan yang sangat sibuk dan memiliki potensi polusi paling besar, langkah mendasar dari upaya tersebut adalah dengan membatasi jumlah pengunjung atau dengan mengukur berapa besar kekuatan hutan kota dalam menampung pengunjung yang datang, seterusnya pada penelitian ini bertujuan memberikan gambaran jumlah maksimal pengunjung perharinya. Dengan asumsi jam operasional selama 8 jam, maka untuk Hutan kota di Kota Makassar. $P C C=A / B(R f) \ldots$ (fandely,2018), berikutnya $P C C=4,900 \mathrm{~m}^{2} / 65^{\mathrm{m} 2} \times 4$. Maka dapat di peroleh jumlah pengunjung maksimal perhari itu adalah \pm 302 orang dengan jumlah kebutuhan perorang lama menikmati kunjungan 2 jam. Asumsi tersebut diatas memberikan gambaran tentang jumlah maksimal kunjungan yang hanya boleh \pm 302 orang saja dalam seharinya, dengan pertimbangan ruang gerak setiap pengunjung, potensi sampah yang timbul, serta resiko lain yang dapat timbul, haltersebut perlu di perhatikan bagi pengelolah jikalau ingin mempertahankan kelestarian Hutan Kota, dan menjaga keberlajutan kawasan wisata, namun hal tersebut tidaklah mudah karena banyak keterlibatan lain yang memang di berikan kesadaran kepada masyarakat perkotaan akan pentingnya hutan kota yang sudah mereka miliki.

\subsection{Pengelolaan Hutan Kota}

Adanya taman edukasi berupa Hutan Kota diharapkan, agar masyarakat mendapatkan wawasan tentang keanekaragaman vegetasi dengan berbagai manfaatnya. Konsep ini diharapkan dapat mewujudkan Go Green pada lingkungan Kota khususnya kawasan Hutan di Kota Makassar, utamanya pada Kecamatan Ujung Pandang, dan kecamatan sekitarnya. selanjutnya Taman atau Hutan Kota merupakan ruang publik yang akan dikunjungi banyak orang dengan berbagai ragam usia maupun latar belakang berbeda, maka perlu dilakukan pertimbangan dalam pengelolaannya, hal ini dapat dengan melakukan study komperatif, terhadap kota-kota yang memiliki pengelolaan hutan kota yang baik, dalam penelitian ini sebagai studi komperatifinya adalah Hutan Kota Kelurahan Ballang, Kabupaaten Jeneponto yang sudah berbentuk sebuah kajian berupa masterplant pengembangan, berikutnya pengelolaan taman Hutan Kota yang relatif memberikan dukungan kenyamanan dan keamanan bagi penggunanya, perihal ini sejalan dengan apa yang dikemukakan peneliti terdahulu bahwa dalam pengembangan sebuah kawasan sebaiknya memiliki perencanaan yang kuat dan matang (Yes \& Cieszewski, 2020)Aplikasinya dapat diterapkan hal-hal sebagai berikut: (1). Pengawasan pada area yang terbuka untuk umum utamanya waktu di malam hari dengan cara pembatasan yang dapat dibuatkan berupa pagar pengaman, hal ini juga dapat mencegah masyarakat sekitar yang bersifat tidak baik dengan melakukan pendalisasi, atau perusakan fasilitas yang tersedia. (2). Pemasangan penerangan yang baik dan seperti Lampu Halaman yang strategis utamanya untuk area yang memungkinkanaktifitas negatip dari pengunjung Dark Spot (Area Gelap) yang terbuka untuk umum. (3). Penempatan pos jaga yang mudah diakses dan melakukan pemantauan, juga didukung oleh satuan petugas keamanan yang sifatnya dapat mobile dengan penggunaan sarana seperti sepeda, sepatu roda atau dengan berjalan kaki, bahkan bisa dimungkinkan dengan sekuter. (4). Dalam Komplek Hutan Kota juga menyediakan ruang pertolongan pertama (P3K)

Sebagai bahan kajian yang merupakan studi komperatif yang telah ada seperti pada gambar 3. Pemetaan dan pengelolaan Hutan Kota : 


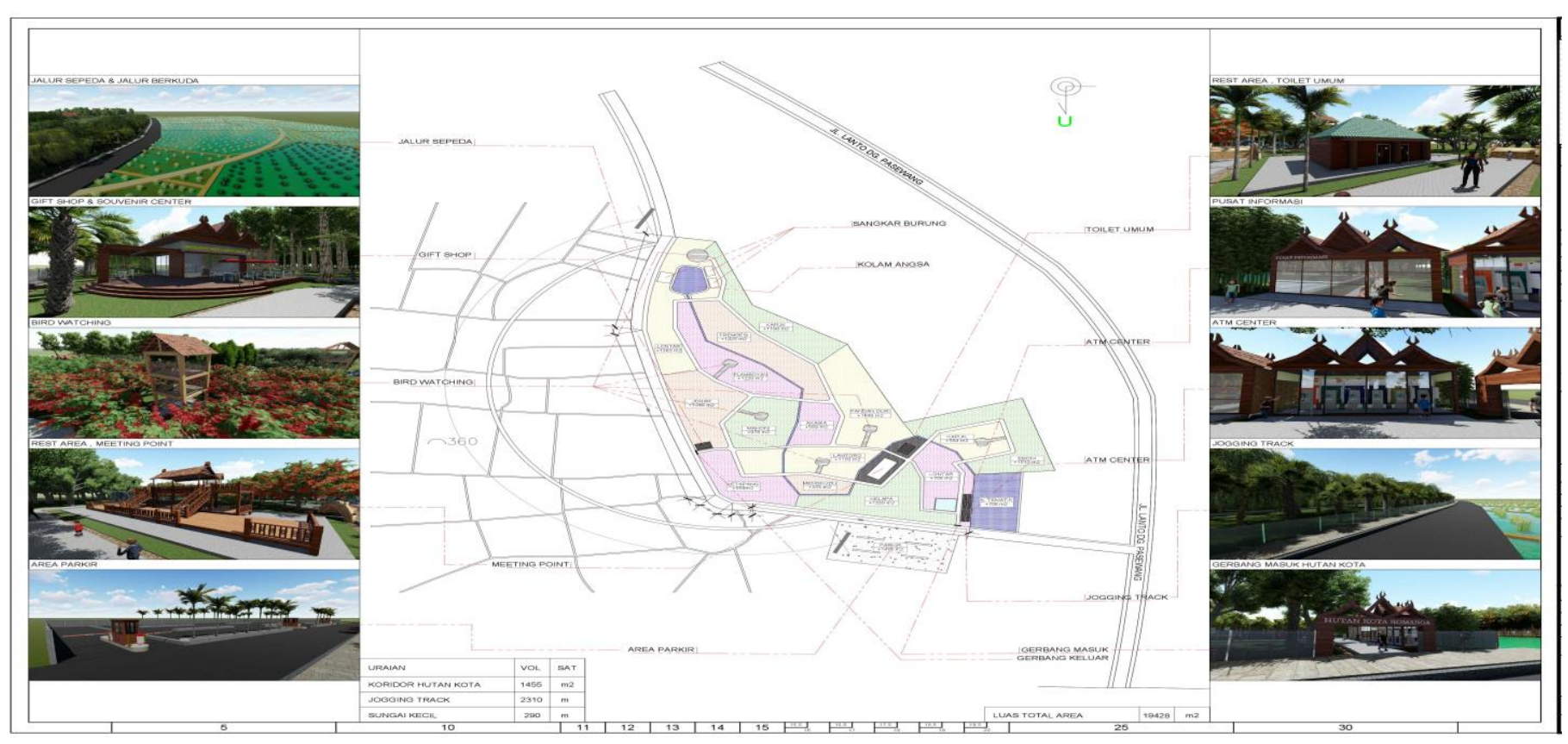

\section{Gambar 3. Pada pemetaan dan pengelolaan Hutan Kota Sumber: Data Olahan Penelitian, 2019}

\section{Kesimpulan}

Upaya pelestarian hutan kota yang terdapat di Kota Makassar akan dapat diwujudkan apabilah telah di ketahui daya tampung pengunjung yang akan melakukan aktifitas wisatanya, Hutan kota di Kota Makassar, dengan luas wilayah $4,900 \mathrm{~m}^{2}$ sebaiknya pengunjung maksimal perhari itu adalah \pm 302 orang dengan jumlah kebutuhan perorang lama menikmati kunjungan 2 jam, dengan pertimbangan ruang gerak setiap pengunjung, potensi sampah yang timbul, serta resiko lain yang dapat timbul kesadaran masyarakat sekitar kawasan dan yang paling penting adalah regulasi yang kuat untuk menjaga bersama-sama hutan kota tersebut atau taman macan, 5 (lima) pilar fasilitas pariwisata di kawasan pada umumnya sudah ada namun dalam penggunaannya kurang baik, Master plant dari Hutan Kota di Jeneponto yang mirip untuk kajian pada taman macan dapat menjadi perbandingan yang positif.

\section{Referensi}

Andong, S., \& Ongolo, S. (2020). From global forest governance to domestic politics: The European forest policy reforms in Cameroon. Forest Policy and Economics, 111(October 2019), 102036. https://doi.org/10.1016/j.forpol.2019.102036

Baumeister, C. F., Gerstenberg, T., Plieninger, T., \& Schraml, U. (2020). Exploring cultural ecosystem service hotspots: Linking multiple urban forest features with public participation mapping data. Urban Forestry and Urban Greening, 48, 126561. https://doi.org/10.1016/j.ufug.2019.126561

Bonilla-Bedoya, S., Mora, A., Vaca, A., Estrella, A., \& Herrera, M. Á. (2020). Modelling the relationship between urban expansion processes and urban forest characteristics: An application to the Metropolitan District of Quito. Computers, Environment and Urban Systems, 79(July), 101420. https://doi.org/10.1016/j.compenvurbsys.2019.101420

Guadilla-Sáez, S., Pardo-de-Santayana, M., \& Reyes-García, V. (2020). Forest commons, traditional community ownership and ecological consequences: Insights from Spain. Forest Policy and Economics, 112(January), 102107. https://doi.org/10.1016/j.forpol.2020.102107 
Kobi, W., \& Hendra, H. (2020). Kajian Geografi Ekonomi: Studi Kasus Kondisi Sosial Ekonomi Masyarakat Suku Bajo Di Popayato, Gorontalo. Jambura Geo Education Journal, 1(1), 16-25. https://doi.org/10.34312/jgej.v1i1.4637

Mondal, P., McDermid, S. S., \& Qadir, A. (2020). A reporting framework for Sustainable Development Goal 15: Multi-scale monitoring of forest degradation using MODIS, Landsat and Sentinel data. Remote Sensing of Environment, 237(December 2019), 111592. https://doi.org/10.1016/j.rse.2019.111592

Musawantoro, M., \& Ridwan, M. (2019). Potensi Pantai Panrangluhung di Bira Kabupaten Bulukumba sebagai Destinasi Wisata. Jurnal Kepariwisataan: Destinasi, Hospitalitas Dan Perjalanan, 3(1), 1-7. https://doi.org/10.34013/jk.v3i1.27

Ordóñez, C., Threlfall, C. G., Livesley, S. J., Kendal, D., Fuller, R. A., Davern, M., van der Ree, R., \& Hochuli, D. F. (2020). Decision-making of municipal urban forest managers through the lens of governance. Environmental Science and Policy, 104(May 2019), 136-147. https://doi.org/10.1016/j.envsci.2019.11.008

Sonti, N. F., Campbell, L. K., Svendsen, E. S., Johnson, M. L., \& Novem Auyeung, D. S. (2020). Fear and fascination: Use and perceptions of New York City's forests, wetlands, and landscaped park areas. Urban Forestry and Urban Greening, 49, 126601. https://doi.org/10.1016/j.ufug.2020.126601

Sunarty S. Eraku, S. K. (2018). Community Based Environmental Conservation In The Motilango Village, Gorontalo Utara Regency. Jurusan Ilmu Dan Teknologi Kebumian, Fakultas MIPA, Universitas Negeri Gorontalo, 6(1), 107-113. https://doi.org/https://doi.org/10.29313/ethos.v6i1

Yes, A., \& Cieszewski, C. (2020). Mapping of recreation suitability in the Belgrad Forest Stands. January. https://doi.org/10.1016/j.apgeog.2020.102153 